\title{
A Miles-Snow-féle stratégiai tipológia statisztikai tesztelése szabályozott ágazati környezetben II.
}

\section{Csepeti Ádám,}

a Budapesti Corvinus Egyetem egyetemi adjunktusa

E-mail:

adam.csepeti@uni-corvinus.hu

\section{Bover Andrós,}

a Budapesti Corvinus Egyetem egyetemi tanára

E-mail:

andras.bauer@uni-corvinus.hu
A szerzők a Miles-Snow-féle stratégiai orientációk érvényesülését és üzleti teljesítményvonatkozásait vizsgálták a hazai lakossági gyógyszerellátási ágazatban. Tanulmányuk első részében a stratégiai tipológiát, valamint a köz- és magánjavak sajátos keveredésével jellemezhető magyarországi lakossági gyógyszerellátási ágazat sajátosságait ismertették. Mindemellett bemutatták konceptuális modelljüket és megfogalmazták kutatási kérdéseiket, hipotéziseiket is. A második részben empirikus adatfelvételüket ismertetik és összefoglalják a kutatás eredményeit, következtetéseit. Többváltozós statisztikai módszertannal bizonyították be, hogy Miles és Snow 4 ,tiszta”, ideáltipikus stratégiai orientációja nem figyelhető meg az ágazatban. A szerzők azt is igazolták, hogy a restriktív makrokörnyezeti tényezők és a kedvezőtlen keresleti feltételek negatív hatásai részben kompenzálhatók a tudatosan megválasztott, proaktív, piacorientált stratégiai orientációk konzisztens implementációjával. Ennek eléréséhez a gyógyszerészek menedzseri ismereteinek és gazdálkodási kompetenciáinak átfogó fejlesztése szükséges.

TÁRGYSZÓ:

Miles-Snow-féle stratégiai orientációk.

Gyógyszertári gazdálkodás.

Üzleti teljesítmény.

DOI: $10.20311 /$ stat2018.07.hu0661 
Tanulmányunk első részében bemutattuk vizsgálatunk relevanciáját, szakirodalmi hátterét, valamint a Miles-Snow-féle (továbbiakban gyakran MS) (MilesSnow [1978]) stratégiai tipológia ágazatspecifikus megnyilvánulására megfogalmazott kutatási kérdéseinket (Csepeti-Bauer [2018]). (Lásd a Függelék F1. táblázatát.) Egy bonyolult, alapvetően a profitorientált szférában kialakított, sokváltozós stratégiai tipológiát teszteltünk olyan ágazatban - a magyar gyógyszertárak körében -, ahol a piaci verseny erősen szabályozott környezetben zajlik. A stratégiai tipológia amelyet Miles és Snow stratégiai orientációnak nevez - lényege, hogy a legtöbb piacon 4 eltéró vállalatcsoport azonosítható. „A Kutatók folyamatosan új termékekkel/fogyasztói szegmensekkel kapcsolatos üzleti lehetőségek felkutatására és megragadására törekednek. A Védekezők konvencionális megoldásaikkal egy stabil termék/piaci szegmens hatékony kiszolgálását tekintik prioritásnak. A stratégiai alkalmazkodási mozgástér közepén levő Elemzők egyszerre kívánják biztosítani a költséghatékonyságot és kiaknázni a termékinnovációban rejlö lehetőségeket. Az előző 3 stratégiai orientációval szemben a Reagálók nem képesek kialakítani konzisztens, a sikeres környezeti alkalmazkodáshoz szükséges, tudatos magatartásmintát." (Csepeti-Bauer [2018] 579. old.)

Kutatásunkban a stratégia és a teljesítmény kapcsolatát elemeztük, amelyet több más tényezö (a piaci szereplök által észlelt környezeti bizonytalanság [PEU - perceived environmental uncertainty] és a kereskedelemben fontos telephely) is befolyásol (moderál). A gyógyszertárak által potenciálisan követett MS-féle stratégiai orientációk és az üzleti teljesítmény közötti kapcsolatra megfogalmazott és tesztelt kutatási hipotéziseink az F2. táblázatban olvashatók. A továbbiakban a kutatás módszertanát, a feltárt eredményeket és az azokhoz kapcsolódó következtetéseket mutatjuk be.

\section{Az alkalmazott kutatási módszertan}

Vizsgálatunkban primer és szekunder kutatásmódszertani eszközöket is alkalmaztunk az ágazatban megfigyelhető alkalmazkodási magatartásminták azonosítására és az üzleti teljesítménnyel való kapcsolatuk elemzésére. Az ágazat érintett csoportjainak képviselőivel szakértői mélyinterjúkat folytattunk. A több mint 30 konzultáció során véglegesítettük a konceptuális modellünket, valamint a patikusokkal közösen érvényességi, megbízhatósági és dimenzionalitási előteszteknek vetettük alá a kérdőíves kutatásban alkalmazandó mérőeszközöket. Mintavételi technikánk nem tekinthe-

Statisztikai Szemle, 96. évfolụam 7. szóm 661-682. oldal 
tő véletlennek, mintavételi keretünket a Budapesten és 4 megyében (Baranya, Borsod-Abaúj-Zemplén, Pest és Vas) müködő közforgalmú gyógyszertárak képezték, így az nem reprezentálja a patikák országos sokaságát. Az ezekben a megyékben működő gyógyszertárak ugyanakkor jól mutatják az egyes régiók fejlettségi és müködési színvonalát. A vizsgált területi egységekben kérdőívünket cenzusjelleggel, mintegy ezer gyógyszertárvezetőhöz juttattuk el hagyományos postai úton, nyomtatott formában. ${ }^{1}$ Az emlékeztető levelek és telefonhívások után összesen 207, a statisztikai elemzésekben felhasználható, minőségi adatokat tartalmazó kitöltött kérdőív érkezett vissza, ami körülbelül 22 százalékos válaszadási arányt jelent.

A MS-féle stratégiák operacionalizálására egyszerre 3 extrakciós módszert is használtunk (Snow-Hambrick [1980]). 1. Az önkitöltös bekezdések technika pár sorban összefoglalja a Kutatók, Elemzők, Védekezők és Reagálók stratégiai magatartását, amely opciók közül a válaszadó gyógyszerészeknek ki kellett választaniuk azt, amelyik a leginkább jellemző patikájuk környezeti alkalmazkodására. 2. A Segevféle [1987] - az ágazatban megfigyelhető stratégiai magatartásminták feltárására alkalmazott - többtételes skála nemzetközi kutatásokban már többször igazolta érvényességét és megbízhatóságát. Ez a mérőeszköz az MS-i stratégiák ideáltipikus aspektusaira megfogalmazott állításokat értékeltette 1-től (egyáltalán nem jellemző gyógyszertárunkra) 5-ig (teljes mértékben jellemző patikánkra) terjedő Likert-skálán. 3. Végül, a gyógyszertárakat a patikai menedzsmentre jellemző objektív indikátorok (például a vényköteles, a vény nélkül kapható és az egyéb termékek megoszlási aránya [\%] az árbevételben) segítségével is igyekeztük stratégiai típusokba sorolni a leadott értékelések kvartilisei alapján.

A Segev-skála [1987] alkalmazása kiválóan szolgálta azon kiemelt módszertani célkitüzésünket, hogy a patikák által követett stratégiai orientációkat látens konstrukcióként operacionalizáljuk, és SEM-technikákkal (structural equation modeling strukturális egyenletek modellezése) hozzuk összefüggésbe más látens vagy explicit változókkal (Sajtos-Fache [2005]). A SEM gyakran alkalmazott többváltozós matematikai-statisztikai módszertani eszköztár, amely igen elterjedt a rangos nemzetközi kutatásokban és publikációkban is; egyik nagy előnye, hogy képes az empirikus vizsgálatokban korábban már referált többtételes skálák más kontextusban történő validálására. A SEM-módszerek másik kiemelkedő tulajdonsága, hogy a látens konstrukciók és indikátorváltozók, valamint a látens változók közötti komplex kapcsolatrendszer vizsgálatára is megfelelök (Kaplan [2000]).

A SEM alkalmazásának helyességét igazolja az a tény is, hogy gyógyszertári kutatásunk központi konstrukciója a stratégia, a vállalkozásoknak egy olyan komplex, metodológiai szempontból nehezen megragadható magatartásmintája, amelyet reflektív megközelítésben volt célszerü mérnünk (Diamantopoulos-Siguaw [2006]).

\footnotetext{
${ }^{1}$ Az adatfelvétel lebonyolításában jelentős támogatást nyújtott az MGyK (Magyar Gyógyszerészi Kamara) elnöke és a vizsgálatba bevont megyék vezetői, akiknek köszönjük a támogatást.
} 
Reflektív mérési modellek esetén az oksági folyamatok a látens konstrukcióból az indikátorok irányába tartanak, azaz a látens változóban bekövetkezett változás az indikátorváltozókban is módosulást fog kiváltani (Coltman et al. [2008]).

Ennek alapján abból a feltételezésből indultunk ki, hogy az explicit módon mérhető patikai gazdálkodási jellemzők megnyilvánulásának okozó tényezője a közös látens konstrukció, a patikák környezeti alkalmazkodásában nehezen megfigyelhető magatartásminta a stratégiai orientáció (Bourgeois [1980], Bollen [1989], HenleyShook-Peterson [2006]). Az adatelemzés során egy CB-SEM-alkalmazást (covariance based structural equation modeling - kovarianciaalapú strukturális egyenletek modellje) használtunk, ${ }^{2}$ mert 1 . relatíve nagy mintaelemszámmal dolgoztunk, 2. adataink normális eloszlást követtek, valamint 3 . fö célunk egy nemzetközileg már bizonyított elmélet általános, modelljellegü tesztelése volt a köz- és magánjavak keveredésével jellemezhető lakossági gyógyszerellátásban, melyre az választható varianciaalapú technikák (például a PLS-módszer [partial least squares - parciális legkisebb négyzetek]) kevésbé alkalmasak (Kazár [2014]).

A patikák üzleti teljesítményét hatásossági (nettó értékesítési árbevétel) és hatékonysági (adózás utáni eredmény) mutatókra való közvetlen rákérdezéssel mértük. A patikusok PEU-ját Miles és Snow [1978] többtételes skálájával operacionalizáltuk. A válaszadó gyógyszerészeknek 7 dimenzió (a nagykereskedők, a gyártók, a betegek, a versenytárs patikák, a szabályozó hatóságok, az MGyK magatartása és a pénzügyi feltételek alakulása), valamint a hozzájuk tartozó 45 indikátorváltozó értékelése alapján kellett véleményt alkotni a bizonytalanság mértékéről. Az értékeléseket 1-től (teljes mértékben kiszámíthatatlan) 5-ig (teljes mértékben kiszámítható) terjedő Likert-skálán rögzítettük. A gyógyszertárak telephelyének operacionalizálása illeszkedett az ágazat gyakorlatához, azaz a település lakosságszáma alapján, ordinális mérési skálán vettük fel. A válaszadók 5 lehetőség közül választhattak: 1 . Budapest, 2. 50 ezer fönél nagyobb város, 3. 10-50 ezer fö közötti város, 4. 5-10 ezer fö közötti település, 5 . 5 ezer fố alatti kistelepülés. Kutatási kérdéseink megválaszolására és hipotéziseink tesztelésére számos egy- és többváltozós statisztikai módszert alkalmaztunk. (Lásd az F3. táblázatot.)

\section{Eredmények}

A kutatási kérdéseinket vizsgáló statisztikai eredményeket a következö bekezdésekben, míg a hipotézisek tesztelésének tapasztalatait az F4. és F5. táblázatban fog-

\footnotetext{
${ }^{2}$ Számításainkat az SPSS Amos programcsomag segítségével végeztük.
} 
laltuk össze. Ebben a fejezetben a kutatás „nyers” - döntően kvantitatív - eredményeit ismertetjük, míg a tapasztalatok szöveges, átfogó értelmezésére a 3. fejezetben teszünk kísérletet.

Feltártuk, hogy az ágazatban nem figyelhető meg mind a 4 MS-féle eredeti stratégiai magatartásminta. A Segev-féle többtételes skála az EFA (exploratory factor analysis - exploratív faktorelemzés) és a CFA (confirmatory factor analysis konfirmatív faktorelemzés) szerint a Védekező és Reagáló magatartás jellemzői jelentős mértékben ugyanazt a faktort töltötték fel. (Lásd az F1. ábrát.) A Védekezők/Reagálók „mix” azonosításával - a Kutatókkal és Elemzőkkel együtt - 3 stratégiát figyeltünk meg a gyógyszertárak alkalmazkodásában. (Lásd az F1. táblázat K1et.) A Segev-féle többtételes skála EFA és CFA elemzései szerint a Védekező és Reagáló magatartás jellemzői jelentős mértékben ugyanazt a faktort töltötték fel. Az F1. ábrán feltüntettük a Segev - a Miles-Snow-féle stratégiai orientációk operacionalizálására kidolgozott - mérési skála azon konfirmatív faktorstruktúráját, amely az illeszkedési mutatók alapján a leginkább megfelelően reprodukálta empirikus adatainkat. Az ágazatspecifikus Védekező/Reagáló stratégiai orientáció azonosítása kapcsán itt szeretnénk felhívni a figyelmet, hogy a kutatási kérdéseinkben és hipotéziseinkben szerepeltetett, külön-külön a Védekezőkre és a Reagálókra megfogalmazott állítások többsége így inadekváttá vált. Ezért az eredményeinket összefoglaló F6. és F7. táblázatban ezeket a kutatási részkérdéseket és alhipotéziseket a már „,nem releváns" értékeléssel szerepeltettük.

A CFA során megerősített 3 faktoros struktúra főbb illeszkedési mutatói kielégítették a módszertani szakirodalom kritériumait (Hu-Bentler [1999]). Az illeszkedési mutatók: CMIN/d. f. = 1,968 (CMIN [minimum discrepancy - minimum eltérés], d. f. [degrees of freedom - szabadságfok]), RMSEA $=0,059$ (RMSEA [root mean square of approximation - a reziduumok négyzetes középértéke]), CFI =0,903 (CFI [comparative fit index - komparatív illeszkedési index]). A Cronbach-alfa együtthatók (Kutatók $=0,887$, Elemzők $=0,865$, Védekezők/Reagálók $=0,875)$ meghaladták a 0,7-et, míg a CR-értékek (composite reliability - összetétel-megbízhatóság) (Kutatók $=0,935$, Elemzők $=0,919$, Védekezők/Reagálók $=0,923$ ) megerösítik a látens konstrukciókat operacionalizáló skála megbízhatóságát az indikátorváltozókkal együtt. Az ágazatspecifikus 3 faktoros megoldás AVE-mutatói (average variance extracted - átlagos kivonatolt variancia) meghaladták a 0,5-es értéket (Kutatók $=0,622$, Elemzők $=0,564$, Védekezők/Reagálók $=0,527$ ), ezáltal a mérőeszköz konvergencia- és diszkriminanciaérvényessége (Fornell-Larcker-kritérium ${ }^{3}$ ) is igazolódott (Fornell-Larcker [1981]).

A PEU-skála hasonlóan jól teljesített az EFA- és CFA-vizsgálatok során, az illeszkedési mutatók $(\mathrm{CMIN} / \mathrm{d}$. $\mathrm{f} .=1,495, \mathrm{RMSEA}=0,05, \mathrm{CFI}=0,925)$ meghaladták

\footnotetext{
${ }^{3}$ A Fornell-Larcker-teszt szerint az adott látens változó AVE-értékének magasabbnak kell lennie, mint a kérdéses és a többi látens változó közötti korreláció négyzete.
} 
a küszöbértékeket, azaz az eredeti 8 faktoros megoldást az adatstruktúra jól reprodukálta. A megbízhatóságot mérő Cronbach-alfa együtthatók minden faktornál kielégítették a 0,7-es kritériumot (nagykereskedők $=0,720$, gyártók $=0,788$, betegek $=0,773$, versenytárs gyógyszertárak $=0,910$, szabályozó hatóságok $=0,875$, MGyK $=0,885$, pénzügyi feltételek $=0,854$ ). A CR-értékek alapján (nagykereskedők $=0,787$, gyártók $=0,802$, betegek $=0,824$, versenytárs gyógyszertárak $=0,917$, szabályozó hatóságok $=0,884, \mathrm{MGyK}=0,890$, pénzügyi feltételek $=0,861$ ) e látens konstrukciót mérö többtételes skála kompozit megbízhatósága is megerősíthető. Az AVE-mutatók (nagykereskedők $=0,569$, gyártók $=0,593$, betegek $=0,585$, versenytárs gyógyszertárak $=0,780$, szabályozó hatóságok $=0,608, \mathrm{MGyK}=0,748$, pénzügyi feltételek $=0,581$ ) is meghaladták a 0,5 -es módszertani küszöbértéket (Baumgartner-Homburg [1996]), megerösítve ezzel a skála konvergencia- és diszkriminanciaérvényességét.

Mindkét skálánál leszögezhetjük, hogy a látens konstrukciókhoz tartozó egyetlen indikátorváltozó standardizált regressziós együtthatója sem maradt el a Churchill [1979] által meghatározott 0,4-es küszöbértéktől, így egyet sem távolítottunk el. A skálák konstrukcióérvényességét a nomológikus-, konvergencia- és diszkriminanciaérvényességet vizsgáló tesztekkel értékeltük, utóbbit 6-féle eljárással is (EFA, CFA, indikátorok megbízhatósága, látens konstrukciók kovarianciája, CFA-modellek összehasonlítása és Fornell-Larcker-kritérium) alátámasztottuk. A CMV-ből (common-method variance - közösmódszer-torzítás) Harman-féle egyfaktoros teszttel, az egy közös látens faktor és a „marker” változós technikával is teszteltük, mindhárom eredményei szerint a CMV egyik skálánk érvényességét sem befolyásolta (Podsakoff et al. [2003]). Az egyes tételekre adott értékeléseknél is megvizsgáltuk a nemválaszolásból származó torzításokat (Groves et al. [2001]). Az ANOVA-táblák (analysis of variance - varianciaanalízis) nem jeleztek eltéréseket a korai és késői válaszadók értékelései között, tehát a nemválaszolás problematikája nem torzította mérési eredményeink érvényességét, általánosíthatóságát.

Visszatérve a MS-féle tipológia ágazatspecifikus megnyilvánulásához, az EFA és a CFA alapján a Védekezö/Reagáló orientáció nem tekinthető a gazdálkodási aspektusokat szervesen ötvözö, hibrid magatartásmintának, hanem a Védekezők és a Reagálók egyszerü „mixeként” értelmezhető. (Lásd az F1. táblázat K2-őt.) Ugyanis a faktorstruktúra részletes elemzésekor megállapítottuk, a Védekező és Reagáló tételek nem egymással „keveredve” töltik fel ezt a faktort, hanem a Védekező állítások a Védekezőkkel, míg a Reagáló állítások a Reagálókkal „„tömörültek” egymás ,alatt”. A Védekező és Reagáló gazdálkodási jellemzők érvényesülésére adott gyógyszerészi értékelések súlyozott átlagai alapján kijelenthető az is, hogy az inkonzisztens Reagálók magatartási aspektusai dominálnak ebben az alkalmazkodási mintában. Az ágazatban azonosított 2 ,tiszta” és 1 „mix” stratégiai orientáció egymástól nemcsak a CFA alapján különböztek, hanem a Tukey-Scheffe-Bonferroni-tesztek (Savin [1980]) 
is szignifikáns eltéréseket jeleztek a Kutatók, az Elemzők és a Védekezők/Reagálók gazdálkodási jellemzői között.

A két sikeresen alkalmazott stratégiai extrakciós technika - a Segev-féle többtételes skála és az önkitöltős bekezdések módszere - klasszifikációs eredményei között minimális eltérést tapasztaltunk, így a két mérőeszköz konvergens érvényessége fennáll. (Lásd az F1. táblázat K3-at.) A McNemar-féle $\chi^{2}$-próba páros összehasonlításainak inszignifikánciája azt jelzi, hogy a Kutatók, az Elemzők és a Védekezők/Reagálók azonosítására használt eltérő mérőeszközök besorolási eredményei (Védekezők/Reagálók: $\chi^{2}=0,22$, szignifikanciaszint $=0,883$; Kutatók: $\chi^{2}=1,641$, szignifikanciaszint $=0,200 ; \quad$ Elemzők: $\quad \chi^{2}=0,522, \quad$ szignifikanciaszint $=0,470$; $p=0,05)$ nem különböztek egymástól. A megnövekedett versenyintenzitás ellenére a patikák relatív többsége inkonzisztens Védekezö/Reagáló stratégiával rendelkezik, őket követik az Elemzők, míg a - turbulens jogszabályi változásokban levő üzleti lehetőségeket proaktívan kereső, termékportfóliójukat bővítő - Kutatók relatív kisebbsége figyelhető meg. (Lásd az F1. táblázat K4-et.) Eredményeinket páros mintás $t$-próbákkal is megerösítettük, ahol a Kutató, Elemző és Védekezö/Reagáló patikákat dummy változók alapján kódoltuk.

A különböző stratégiát követő patikusok eltérő mértékben észlelték bizonytalannak a környezeti feltételek alakulásában és az érintettek magatartásában megfigyelhető változásokat. (Lásd az F1. táblázat K5-öt.) Az Elemzök kiszámíthatóbbnak ítélték meg a környezeti módosulásokat, mint a Kutatók és Védekezők/Reagálók. Nincs szignifikáns eltérés a Kutató, Elemző és Védekező/Reagáló patikák megoszlásában az alacsony és magas bizonytalansággal jellemezhető csoportok között. (Lásd az F1. táblázat K6-ot.) A stratégiát és a bizonytalanságot másodrendű konstrukcióként operacionalizálva, SEM segítségével tártuk fel, hogy a gyógyszertárvezetők tudatos stratégiai választása erőteljesebb befolyást gyakorolt a környezeti bizonytalanság mértékére $(\beta=0,174$, szignifikanciaszint $=0,042, \quad \mathrm{CMIN} / \mathrm{d}$. $\mathrm{f} .=1,967, \quad \mathrm{CFI}=0,889, \quad \mathrm{RMSEA}=0,057$ és SRMR $=0,0987$ (SRMR [standardised root mean square residual - standardizált reziduális négyzetes középérték])), mint amilyen mértékben az iparági feltételek determinálták a gyógyszerészeket a stratégia választásában és követésében $(\beta=0,043$, szignifikanciaszint $=0,650, \quad \mathrm{CMIN} / \mathrm{d} . \mathrm{f} .=1,970, \quad \mathrm{CFI}=0,882, \quad \mathrm{RMSEA}=0,058$ és SRMR = 0,1007). (Lásd az F1. táblázat K7-et.) Az SRMR-indikátor - amelynek értéke meghaladta a módszertani szakirodalomban megjelölt 0,08-as küszöbértéket - kivételével a strukturális modellek illeszkedési mutatói elfogadhatók (Hu-Bentler [1999]).

Az MS-i stratégiák teljesítményimplikációinak, valamint a gyógyszertárvezetők PEU-ja és a patika telephelye moderáló hatásának feltárására alkalmazott strukturális modellek illeszkedési mutatóit a következő táblázatban jelenítettük meg.

A táblázatból látható, hogy az SRMR-indikátor - amelynek értéke meghaladta a módszertani szakirodalomban megjelölt 0,08-as küszöbértéket - kivételével illeszkedési mutatóink megfelelnek a szakirodalom elöírásainak (Chen et al.[2009]). 
Strukturális modelljeink illeszkedési mutatóinak ismertetése

\begin{tabular}{l|c|c|c|c}
\hline \multicolumn{1}{c|}{ Stratégia hatása } & CMIN/d. f. & CFI & RMSEA & SRMR \\
\hline \multirow{2}{*}{ a NÉÁ-ra } & $544 / 357=1,524$ & 0,936 & 0,050 & 0,0906 \\
\hline az AUE-re & $586 / 359=1,633$ & 0,922 & 0,055 & 0,0930 \\
\hline & \multicolumn{3}{|c}{ A PEU moderáló hatása } \\
& $1086 / 692=1,570$ & 0,874 & 0,053 & 0,1034 \\
a NÉÁ-ra & $1175 / 720=1,632$ & 0,854 & 0,056 & 0,1066 \\
\hline az AUE-re & \multicolumn{4}{|c}{ A telephely moderáló hatása } \\
\hline & $1104 / 728=1,517$ & 0,864 & 0,051 & 0,0971 \\
\hline
\end{tabular}

Megjegyzés. CMIN (minimum discrepancy): minimum eltérés; d. f. (degrees of freedom): szabadságfok; CFI (comparative fit index): komparatív illeszkedési index; RMSEA (root mean square of approximation): a reziduumok négyzetes középértéke; SRMR (standardised root mean square residual): standardizált reziduális négyzetes középérték; NÉÁ: nettó értékesítési árbevétel; AUE: adózás utáni eredmény.

Forrás: Saját számítás.

A többcsoportos moderációknál a feltétel nélküli és feltételes modellek közötti általános diszkrepancia, valamint a standardizált regressziós együtthatók útvonalankénti különbségeinek szignifikanciáját is teszteltük a magas és alacsony PEU-val jellemezhetö, illetve városi és rurális patikák csoportjai között. Az interakciós moderációnál a fö- és interakciós hatásokat számszerűsítő változókat egy inputációs transzformáció után SPSS-ből manifeszt változóként integráltuk elemzésünkbe, az illeszkedési mutatók így nem számíthatók az AMOS-ban. Az üzletiteljesítményimplikációk aprólékos ismertetése helyett a következökben összefoglaljuk az F4. és F5. táblázatból leszürhető főbb, a kutatási hipotéziseink (H1-H9) tesztelésére vonatkozó megállapításainkat. (Lásd az F2. táblázatot.)

Az ágazatban megfigyelt Kutató, Elemző és Védekezö/Reagáló stratégiai orientációt követő patikák árbevétele eltérő volt $(\mathrm{H1})$, de a különböző stratégiát követő gyógyszertárak jövedelmezősége között eltérést nem tapasztaltunk (H2). A gyógyszertárvezetők PEU-ja - néhány kivételes esettől eltekintve - nem moderálta a patikák stratégiája és üzleti teljesítménye közötti kapcsolatot (H3, H4). A telephely moderáló hatásával kapcsolatban vegyes eredményeket tapasztaltunk (H5, H6). A telephely az interakciós technikák szerint nem, míg a többcsoportos módszerek szerint igenis moderálja e kapcsolatot. Utóbbiak alapján jól megfigyelhetö, hogy a Kutató, Elemző és Védekezö/Reagáló stratégiai orientáció üzleti teljesítményre gyakorolt befolyása jelentősen felerősödik a kevésbé kedvező keresleti feltételek között müködtetett, vidéki gyógyszertárak esetében (H5, H6, H7, H8). 
A feltárt összefüggések többsége robusztus maradt a kontrollváltozók hatásának kiszürése mellett is (H9). A gyógyszertári stratégia teljesítményre gyakorolt hatását tehát nem „nyomták el” olyan szociodemográfiai és telephelyi változók (például teljes alapterület, munkatársak száma, átmenő forgalom, egészségügyi szolgáltatók vagy kiskereskedelmi egységek közelsége), amelyek egyébként jelentékeny addicionális hatással voltak a teljesítményre.

\section{Diszkusszió}

A magyarországi lakossági gyógyszerellátási ágazatban megfigyelhető stratégiai magatartásminták feltárására vonatkozó kutatási kérdéseink esetében megállapítottuk, hogy az erőteljes állami szabályozással, de mégis relatíve magas versenyintenzitással jellemezhető gyógyszerforgalmazási ágazat mikro-, és kisvállalkozásai igenis kialakítanak adaptációs mintákat, csak nem 4-et, hanem 3-at, és nem tiszta, hanem „kevert" stratégiai orientációkat.

Várakozásainkkal ellentétben a gyógyszertárvezetők tudatos stratégiai választásának - a környezeti feltételek észlelésére gyakorolt - befolyása erősebbnek bizonyult a bürokratikus koordinációval jellemezhető környezeti feltételek - a patikák stratégiájának kiválasztását/követését - determináló hatásánál.

Ami a különböző stratégiai orientációkat követő patikák üzleti teljesítményére vonatkozó hipotéziseinket illeti - elözetes mélyinterjús tapasztalataink alapján -, nem volt meglepő, hogy a legmagasabb árbevételt a Kutató gyógyszertárak realizálták. Az új termék/piaci lehetőségek folyamatos megragadása stratégiai jelentőségü, valamint elengedhetetlen a sikeres gyógyszertár-müködtetéshez, különösen a magas versenyintenzitással és/vagy a kedvezötlen keresleti feltételekkel jellemezhetö környezetekben. Ugyanakkor némileg meglepőnek bizonyult, hogy a Kutatók, ugyan nem jelentős mértékben, de a jövedelmezöségben is megelőzték az Elemzőket és a Védekezö/Reagálókat, pedig a szakirodalmi ajánlások szerint a fegyelmezett költséggazdálkodás nem feltétlen tekinthető erösségüknek (Snow-Hambrick [1980]). Lehetséges magyarázatnak tủnik, hogy a hasonló patikák portfóliójának bővítése leginkább a vény nélkül kapható gyógyszerek és egyéb termékek kategóriában realizálódtak, amelyeket magasabb árrések mellett lehet értékesíteni.

Eredményeink többsége azt sugallja, hogy az Elemző stratégia érvényesülése némiképp mérsékelte a gyógyszertárak teljesítményét. Emellett valószínűsíthető, hogy az Elemző stratégia sikeres implementálásához a patikusok nem feltétlen rendelkeztek megfelelő üzleti ismeretekkel és kompetenciákkal, így az innovatív gyógyszerészszakmai és gazdálkodási megoldások bevezetésre irányuló erőforrás-allokációs eröfeszítéseik sikertelennek bizonyultak (Zahra-Pierce [1990]). 
A Védekező/Reagáló stratégia érvényesülése negatív hatást gyakorolt a patikák teljesítményére, ami konzisztens a korábbi kutatásokkal. Eredményeink szerint már sem a magas kereslettel jellemezhetö városi környezet, sem a korlátozott versenyintenzitás nem segít igazán az inkonzisztens stratégiát követő patikákon. A Kutatók és Elemzők teljesítménye viszont meghaladta a Védekezö/Reagálókét, így az prognosztizálható, hogy a jövőben utóbbiak is jelentősebb figyelmet fordítanak majd a kevésbé visszahúzódó stratégiai magatartásminták kifejlesztésére.

A stratégia és teljesítmény közötti sztochasztikus kapcsolatot vizsgáló hipotéziseink esetében megállapítottuk, hogy a gyógyszertárvezetők PEU-jának mértéke nem befolyásolja az előbbi relációt. Ugyanakkor a telephely moderáló hatásának feltárását célzó többcsoportos és interakciós technikák eredményeinek különbözősége kutatásunk módszertani „rejtélyének” tekinthető. A gyógyszertárvezetőkkel és kamarai képviselőkkel készített utólagos interjúk alapján a többcsoportos technikák tapasztalatait fogadtuk el. Logikusnak tünik, hogy a kedvezötlenebb keresleti feltételekkel jellemezhető rurális patikáknál a stratégia tudatos megválasztása és konzisztens implementálása jelentősebb befolyást gyakorol a teljesítményre, mint a nagyobb népességgel, vásárlóerővel és a betegek sokszínű igényeivel szembesülő „védett” városi gyógyszertárak esetében. Tanulmányunk nem igazolta azt, hogy a vidéki gyógyszertárak szuboptimális teljesítményre kárhoztatottak.

Feltételezésünk szerint a gyógyszertárak telephelyi adottságai jelentősen hozzájárulnak a teljesítményhez (Bauer-Mitev [2001], Pillittere-Dugan-Nau-McDonoughPierre [2009]), de egyedül a patika előtti átmenő forgalom volt az, amely az árbevételre és a profitra is pozitív hatást gyakorolt. Elgondolkodtató, hogy még a kórházak, rendelők és kiskereskedelmi egységek közelségének teljesítményre gyakorolt hatásai is csak megközelítették a jelentős mértéket. A patikák teljesítményét tehát inkább a szociodemográfiai jellemzők (például a tulajdonosi szerkezet, a társasági jogi forma) és a stratégiai orientáció határozták meg, együttesen „elnyomva” a telephelyi adottságok parciális hatásait. Ez egyfelől azt jelenti, hogy eredményeink részben ellentmondanak a kiskereskedelmi gazdaságtan tapasztalatainak, másfelöl azonban bizonyítják, hogy egy életképes stratégia tudatos megválasztása és konzisztens implementációja jelentősen képes hozzájárulni a gyógyszertári teljesítmény növeléséhez.

\section{4. Összefoglalás}

Eredményeink ismertetését követően a cikk összefoglalásaként táblázatos formában is összegyüjtöttük a kutatási kérdéseinkre és hipotéziseinkre adott válaszainkat. (Lásd az F6. és F7. táblázatot.) Bebizonyítottuk, hogy az ágazat piaci, jogszabályi és 
gyógyszerészszakmai környezetében zajló változásoknak köszönhetően divergencia tapasztalható a patikák alkalmazkodási magatartásában és teljesítményében.

Kutatásunk föbb korlátai között meg kell említenünk, hogy az MS-féle stratégiák azonosítására eredetileg tervezett 3 technika közül csak 2 extrakciós módszertan alkalmazása sikerült. Az objektív indikátorok módszere nem tudott érdemben hozzájárulni a patikák stratégiai orientációkba sorolásához, azaz a későbbi kutatásokban a különböző mérőeszközök eredményeinek konvergens érvényessége még tovább javítható. Az árbevétellel ellentétben a stratégiai orientáció nem járult érdemben hozzá a gyógyszertárak jövedelmezőségében tapasztalt különbségek magyarázatához. Ugyan SEM-alapú kvantitatív vizsgálataink többségében a legtöbb illeszkedési mutatóra elfogadható eredményeket kaptunk, de az SRMR-indikátor egyetlen modellünknél sem érte el a módszertani szakirodalom által meghatározott küszöbértéket (Bentler-Bonett [1980]). A jövőben el kell mozdulni a keresztmetszeti adatfelvételektől, a stratégiai magatartásminták fejlődése inkább longitudinális adatsorokkal figyelhető meg.

Cikkünk hiányossága, hogy nem sikerült az ágazat fontosabb szociodemográfiai ismérvei alapján véletlen mintát vennünk. Válaszadói mintánk összetétele a településszerkezet, a gyógyszertárak üzleti teljesítménye és társasági jogi formája alapján közelíti a reprezentativitást, ugyanakkor a patikák tulajdonosi szerkezete, a horizontális és vertikális együttmüködési formákban való részvétel szerint nem egyezik meg a hazai gyógyszertári populáció általános összetételével. Mindebből az következik, hogy eredményeink kevésbé általánosíthatók a magyarországi közforgalmú gyógyszertárak teljes sokaságára, így következtetéseink csak kellő körültekintéssel értelmezhetők.

A patikák részvétele a különböző horizontális és vertikális együttmüködési formákban meglepő módon - elképzelhető, hogy a hasonló gyógyszertárak alacsony válaszadási hajlandósági miatt - nem befolyásolta teljesítményüket, így ígéretes és hiánypótló kutatás lehet a „franchise” típusú stratégiai együttmüködésekben, valamint a közös tulajdonosi struktúrában müködő patikai csoportokon belül megfigyelhetö stratégiai magatartásminták vizsgálata.

Ugyanakkor tanulmányunk több tekintetben is hozzájárult a stratégiai menedzsment meglevő tudományos ismerethalmazához. Kutatásunkban igazoltuk, hogy egy, a köz- és magánjavak mikroökonómiai sajátosságainak keveredésével jellemezhető ágazatban, a mikrovállalkozások kontextusában is kimutatható Raymond Miles és Charles Snow korszakos stratégiai tipológiája (Ghobadian et al. [1998]).

Módszertani szempontból kiemelendő, hogy a legtöbb hazai kutatás gyakorlatával ellentétben a vállalkozások által követett stratégiai orientációkat nem explicit mérési eszközökkel közelítettük meg, hanem látens konstrukcióként operacionalizáltuk (Farh-Hoffman-Hegarty [1984]). Bebizonyítottuk, hogy a strukturális egyenletek modellezésével igenis mérhető a gyógyszertárak stratégiai orientációja, amellett igyekeztünk kiküszöbölni a SEM-technikák - stratégiaimenedzsment-kutatásokban 
rendre visszatérő - veszélyeit is (Kazár [2014]). Az adatok normalitásának vizsgálata, a keresztmetszeti kutatások hiányosságainak minimalizálása, számos érvényességi és megbízhatósági teszt elvégzése, a többféle illeszkedési mutató riportolása, valamint a modellek újraspecifikáció nélküli tesztelése kapcsán robusztus eredményeket értünk el (Shook et al. [2004]). A későbbiekben az ekvivalens - az adott látens és indikátorváltozók között más jellegü kapcsolatrendszert feltételező - modellek meglevő adatstruktúrán való tesztelése és az ebből következő lehetséges stratégiaelméleti magyarázatok értékelésére szükséges nagyobb figyelmet fordítanunk (Henley-ShookPeterson [2006]).

Tanulmányunk szektorspecifikus jelentőségét erősíti annak igazolása, hogy a restriktív makrokörnyezeti tényezők és a kedvezőtlen keresleti feltételek negatív hatásai részben kompenzálhatók a tudatosan megválasztott, proaktív, piacorientált stratégiai orientációk implementációjával. Ebből következik, hogy a gyógyszertárak mikro- és ágazati szintü üzleti teljesítményét javítani szándékozó közpolitikai intézkedéseknek a közvetlen beavatkozások mellett nagy hangsúlyt kell fektetniük a patikai gazdálkodás minőségének javítására és az ehhez szükséges gyógyszerészi kompetenciák, menedzseri készségek fejlesztésére (például stratégiai tervezés, piackutatás, termékbevezetés, árazás, készletgazdálkodás, marketingkommunikáció).

\section{Függelék}

A tanulmány kutatási kérdéseinek és részkérdéseinek ismertetése

Kutatási kérdések

K1 A hazai lakossági gyógyszerellátásban a patikák környezeti alkalmazkodási magatartásában megfigyelhetőe Miles és Snow összes stratégiai orientációja?

K2 A hazai lakossági gyógyszerellátásban egymástól markánsan elkülönülö, tiszta vagy hibrid ötvözetstratégiai orientációk azonosíthatók?

K3 A hazai lakossági gyógyszerellátási ágazatban azonosított Kutató, Elemző, Védekező és Reagáló stratégiai orientációt követő patikák aránya milyen mértékben tér el egymástól a különböző mérőeszközök (stratégiai extrakciós technikák) eredményeinek esetében?

K4 Milyen mértékben tér el a magyarországi lakossági gyógyszerellátásban azonosított, különböző MS-féle stratégiai orientációkat követő patikák egymáshoz viszonyított előfordulási aránya? A Kutató stratégiai orientációt követő patikák aránya meghaladja-e a Védekező (K4a) és Elemző (K4b) stratégiai orientációt követő patikák arányát, míg az Elemző stratégiai orientációt követő patikák aránya meghaladja-e a Védekezők arányát $(\mathrm{K} 4 \mathrm{c})$ ? Végül, a Reagáló stratégiai orientációt követő patikák aránya meghaladja-e a Kutató, Védekező és Elemző patikák arányát (K4d)?

(A táblázat folytatása a következő oldalon.) 
(Folytatás.)

Kutatási kérdések

K5 Különbözik-e egymástól a Kutató, Elemző, Védekező és Reagáló stratégiai orientációt követő patikák vezetői által észlelt környezeti bizonytalanság mértéke? A Kutató patikák vezetői által észlelt PEU meghaladja-e az Elemző (K5a) és Védekező (K5c) patikák vezetői, míg az Elemző patikák vezetői által észlelt környezeti bizonytalanság mértéke meghaladja-e a Védekezö patikák vezetői által észlelt környezeti bizonytalanság mértékét (K5b)? Végül, a Reagáló gyógyszertárak vezetői által észlelt környezeti bizonytalanság mértéke meghaladja-e a Kutató, Elemző és Védekező gyógyszertárak vezetői által észlelt környezeti bizonytalanság mértékét (K5d)?

K6 A magas és alacsony környezeti bizonytalanságot észlelő patikák csoportjaiban különbözik-e a Kutató, Elemző, Védekező, Reagáló stratégiai orientációk érvényesülése? A magas környezeti bizonytalanságot észlelő gyógyszertárak csoportjában a Kutatók (K6a) és a Reagálók (K6d) érvényesülése jellemzőbb-e, mint az alacsony környezeti bizonytalanságot észlelő patikák csoportjában? A magas észlelt környezeti bizonytalansággal jellemezhető gyógyszertárak csoportjában a Védekezők (K6b) és az Elemzők (K6c) érvényesülése kevésbé jellemzö-e, mint az alacsony észlelt környezeti bizonytalansággal jellemezhető patikák csoportjában?

K7 A gyógyszertárak által követett stratégiai orientációk észlelt környezeti bizonytalanságra gyakorolt hatása elmarad-e a gyógyszertárvezetők által észlelt környezeti bizonytalanság stratégiai orientációkra gyakorolt hatásától?

F2. táblázat

A tanulmányban tesztelt hipotézisek és alhipotézisek

Hipotézisek

H1 A Kutató, Elemző, Védekező stratégiai orientációk és a patikák NÉÁ-ja közötti kapcsolat erőssége különböznek egymástól. A Kutató (H1a) stratégiai orientáció és a gyógyszertárak NÉÁ-ja közötti pozitív kapcsolat erőssége meghaladja az Elemzők (H1b) és Védekezők (H1c), valamint a gyógyszertárak NÉÁ-ja közötti pozitív kapcsolat mértékét (ebben a sorrendben), míg a Reagáló (H1d) stratégiai orientáció érvényesülése negatív befolyást gyakorol a gyógyszertárak NÉÁ-jának alakulására.

H2 A Kutató, Elemző és Védekező stratégiai orientáció és a patikák AUE-je közötti kapcsolat erőssége különböznek egymástól. A Védekező (H2a) stratégiai orientáció és a gyógyszertárak AUE-je közötti pozitív kapcsolat erőssége meghaladja az Elemzők (H2b) és a Kutatók (H2c), valamint a gyógyszertárak AUE-je közötti pozitív kapcsolat mértékét (ebben a sorrendben), míg a Reagáló (H2d) stratégiai orientáció érvényesülése negatív befolyást gyakorol a gyógyszertárak AUE-jére.

H3 A PEU moderálja a patikák stratégiai orientációja és NÉÁ-ja közötti kapcsolatot. A PEU növekedésével a Kutató (H3a), Elemző (H3b), Védekező (H3c) stratégiai orientáció és a patikák NÉÁ-ja közötti pozitív kapcsolat felerősödik, valamint a Reagáló (H3d) stratégiai orientáció és a patikák NÉÁ-ja közötti negatív kapcsolat is felerösödik.

(A táblázat folytatása a következö oldalon.) 
(Folytatás.)

Hipotézisek

H4 A PEU moderálja a patikák stratégiai orientációja és az AUE közötti kapcsolatot. A PEU növekedésével a Kutató (H4a), Elemző (H4b), Védekező (H4c) stratégiai orientáció és a patikák AUE-je közötti pozitív kapcsolat gyengül, míg a Reagáló (H4d) stratégiai orientáció és a patikák AUE-je közötti negatív kapcsolat felerösödik.

H5 A gyógyszertárak földrajzi elhelyezkedése moderálja a patikák stratégiai orientációja és NEÁ-ja közötti kapcsolatot. Városokban a Kutató (H5a), Védekező (H5b), Elemző (H5c) stratégiai orientáció és a NÉÁ közötti kapcsolat felerősödik a rurális környezetben tapasztaltakhoz képest, valamint a Reagáló (H5d) stratégiai orientáció és a gyógyszertárak NÉÁ-ja közötti negatív kapcsolat is felerősödik.

H6 A gyógyszertárak földrajzi elhelyezkedése moderálja a patikák stratégiai orientációja és AUE-je közötti kapcsolatot. Városokban a Kutató (H6a) és Elemző (H6c) stratégiai orientáció és az AUE közötti pozitív kapcsolat gyengül, míg a Reagáló (H6d) stratégiai orientáció és az AUE közötti negatív kapcsolat felerősödik a vidéken tapasztaltakhoz képest. Rurális környezetben a Védekező (H6b) stratégiai orientáció és az AUE közötti pozitív kapcsolat felerösödik a városokban tapasztaltakhoz képest.

H7 A PEU és a földrajzi elhelyezkedés együttesen moderálják a stratégiai orientáció és a patikák NÉÁ-ja közötti kapcsolatot. Városi környezetben a PEU növekedésével a Kutató (H7a), Elemző (H7b), Védekező (H7c) stratégiai orientáció és a gyógyszertárak NÉÁ-ja közötti pozitív kapcsolat felerősödik a rurális környezetben tapasztaltakhoz képest, valamint rurális környezetben a PEU növekedésével a Reagáló (H7d) stratégiai orientáció és a patikák NÉÁ-ja közötti negatív kapcsolat is felerösödik a városokban tapasztaltakhoz képest.

H8 A PEU és a földrajzi elhelyezkedés együttesen moderálják a stratégiai orientáció és a patikák AUE-ja közötti kapcsolatot. Rurális környezetben a PEU növekedésével a Kutató (H8a), Elemző (H8b), Védekező (H8c) stratégiai orientációk és a patikák AUE-je közötti kapcsolat gyengül, míg a Reagáló (H8d) stratégiai orientáció és a patikák AUE-je közötti negatív kapcsolat felerősödik a városi környezetben tapasztalt mértékhez képest.

H9 A PEU és a földrajzi elhelyezkedés a stratégiai orientáció és a patikák üzleti teljesítménye (NÉÁ és AUE) közötti kapcsolatban játszott moderáló hatására felállított összefüggések robusztusak a lakossági gyógyszerellátási ágazatban releváns kontrollváltozók kiszürése után is.

Megjegyzés. NÉÁ: nettó értékesítési árbevétel; AUE: adózás utáni eredmény; PEU (perceived environmental uncertainty): észlelt környezeti bizonytalanság.

Forrás: Itt és a további táblázatok saját készítésủek. 
A kutatási kérdések és hipotézisek tesztelésére használt többváltozós technikák

Alkalmazott matematikai-statisztikai módszertan

Kérdés

K1 „Önkitöltős” bekezdések technika; objektív indikátorok módszere; EFA; CFA

K2 EFA; CFA; ANOVA; Tukey-Scheffe-Bonferroni-tesztek

K3 Kereszttábla-elemzés; McNemar-teszt

K4 Páros mintás $t$-próbák

K5 Kereszttábla-elemzés; korrelációelemzés; ANOVA; SEM

K6 Kereszttábla-elemzés; korrelációelemzés; ANOVA

K7 Kereszttábla-elemzés; korrelációelemzés; ANOVA, SEM.

Hipotézis

H1 ANOVA; hierarchikus (interakciós) moderációs regresszió; többcsoportos moderációs regresszió; SEM

H2 ANOVA, hierarchikus (interakciós) moderációs regresszió; többcsoportos moderációs regresszió; SEM

H3 Hierarchikus (interakciós) moderációs regresszió; többcsoportos moderációs regresszió; többcsoportos moderáció - SEM; interakciós moderáció - SEM

H4 Hierarchikus (interakciós) moderációs regresszió; többcsoportos moderációs regresszió; többcsoportos moderáció - SEM; interakciós moderáció - SEM

H5 Hierarchikus (interakciós) moderációs regresszió; többcsoportos moderációs regresszió; többcsoportos moderáció - SEM; interakciós moderáció - SEM

H6 Hierarchikus (interakciós) moderációs regresszió; többcsoportos moderációs regresszió; többcsoportos moderáció - SEM; interakciós moderáció - SEM

H7 Moderált moderáció - SEM

H8 Moderált moderáció - SEM

H9 Moderált moderáció - SEM a szociodemográfiai és telephelyi kontrollváltozók integrálásával

Megjegyzés. EFA (exploratory factor analysis): exploratív faktorelemzés; CFA (confirmatory factor analysis): konfirmatív faktorelemzés; ANOVA (analysis of variance): varianciaanalízis; SEM (structural equation modeling): strukturális egyenletek modellezése. 


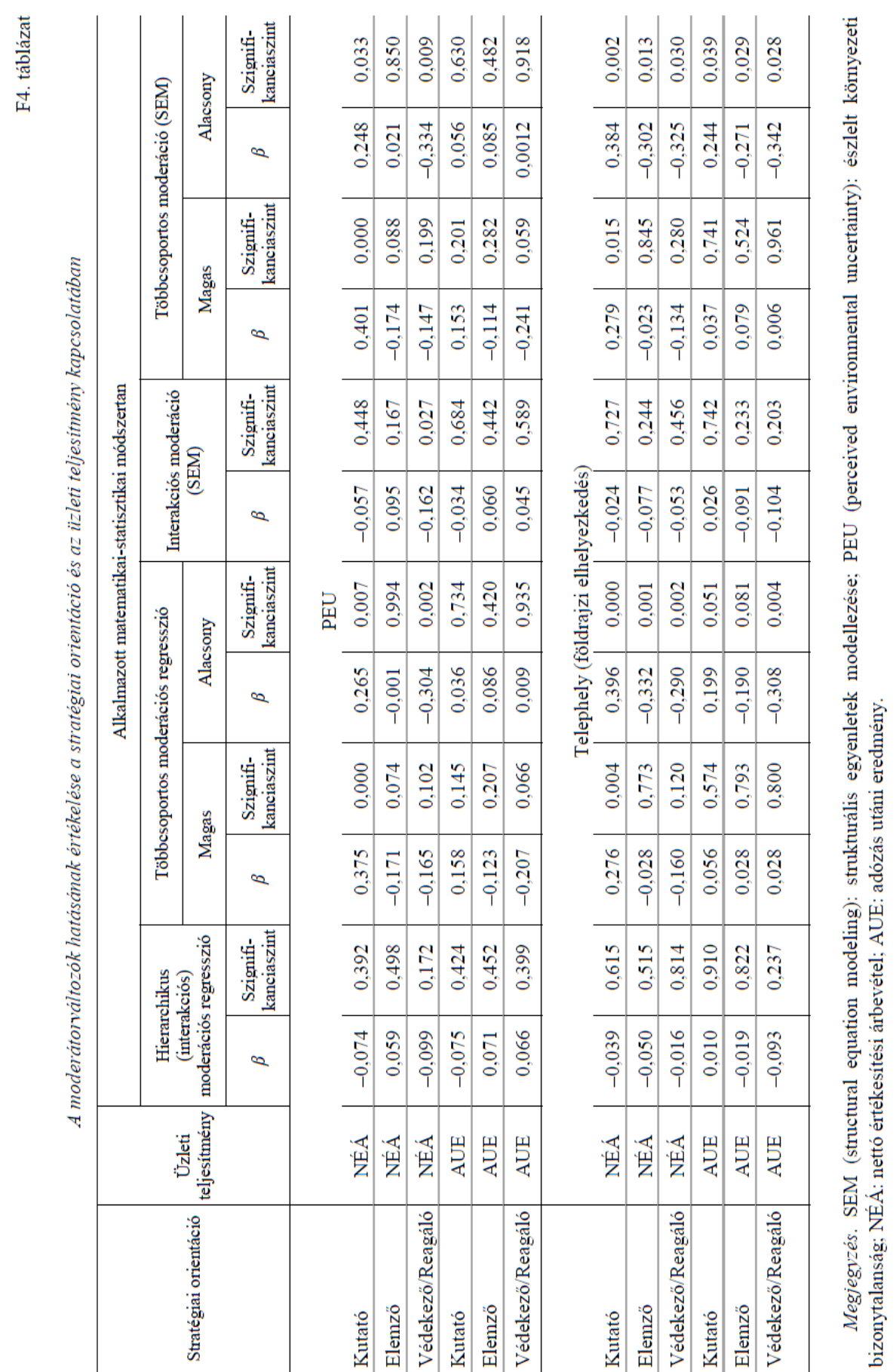




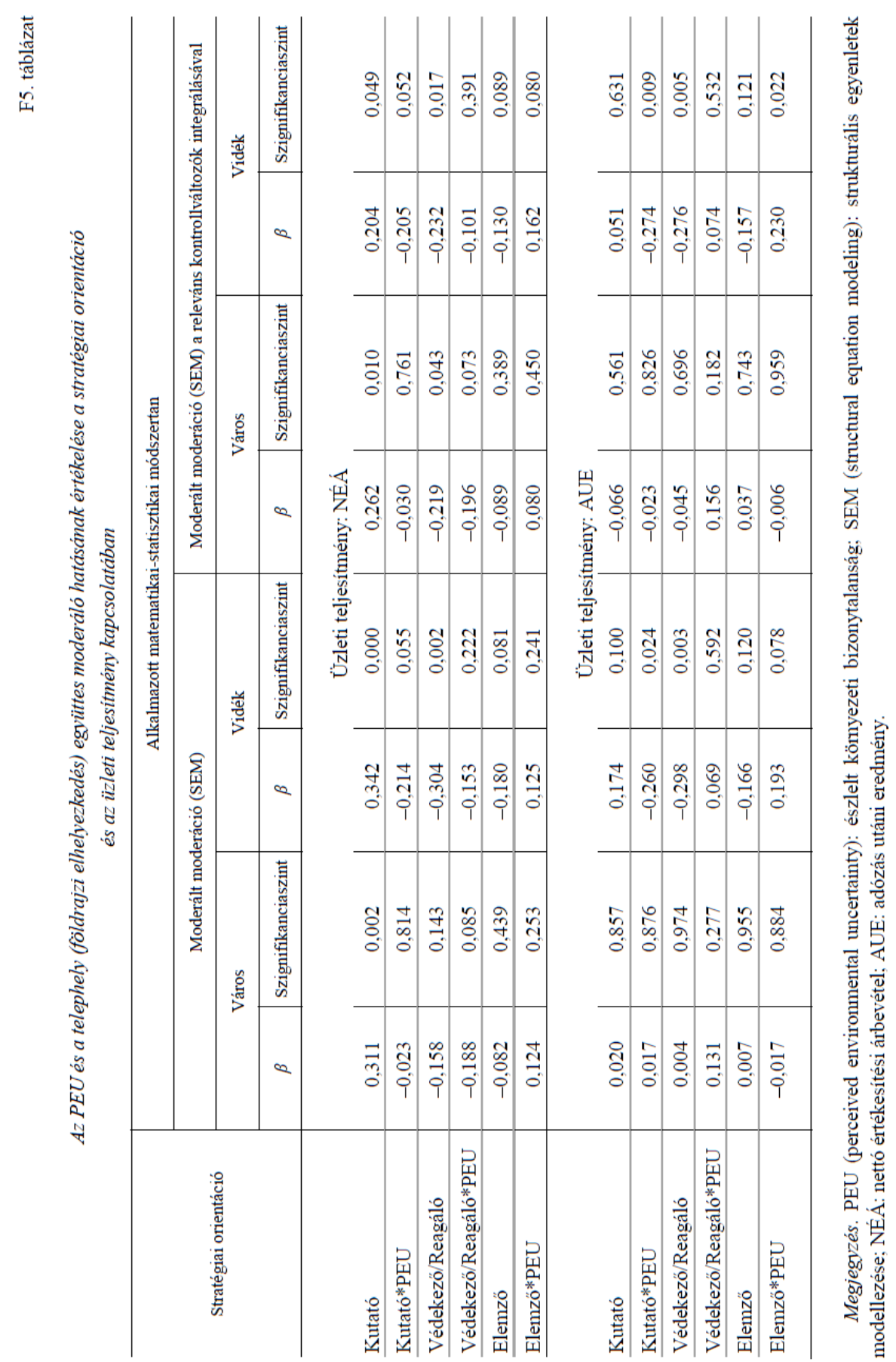


F6. táblázat

Tanulmányunk kutatási kérdéseinek és részkérdéseinek összefoglaló értékelése

\begin{tabular}{|c|c|c|}
\hline \multirow{3}{*}{$\begin{array}{l}\text { Kutatási } \\
\text { kérdés }\end{array}$} & \multicolumn{2}{|l|}{ Kutatási kérdésre adott } \\
\hline & általános & részletes \\
\hline & \multicolumn{2}{|l|}{ válasz } \\
\hline K1 & Nem: nem figyelhető meg az összes MS-i stratégiai orientáció & \\
\hline K2 & $\begin{array}{l}2 \text { tiszta és } 1 \text { hibrid stratégiai orientáció azonosítható, amely } \\
\text { utóbbi inkább egy „mix” magatartásminta }\end{array}$ & \\
\hline K3 & $\begin{array}{l}4 \text { faktor (stratégiai orientáció) esetén: jelentősen eltérő, } \\
3 \text { faktor (stratégiai orientáció) esetén: minimálisan eltérő }\end{array}$ & \\
\hline K4 & $\begin{array}{l}\text { Mindkét módszertan szerint: Védekező/Reagálók (\%) } \geq \\
\text { Elemzők }(\%) \geq \text { Kutatók (\%) }\end{array}$ & $\begin{array}{l}\text { K4a és K4c: nem relevánsak } \\
\text { K4b: Bekezdések: igen; Segev: nem } \\
\text { K4d: Bekezdések: igen; Kutatók: } \\
\text { igen, Elemzők: nem; Segev: igen }\end{array}$ \\
\hline K5 & Igen & $\begin{array}{l}\text { K5a: igen } \\
\text { K5b és K5c: nem relevánsak } \\
\text { K5d: nem (az Elemzőkét igen, } \\
\text { de a Kutatókét nem) }\end{array}$ \\
\hline K6 & Nem & $\begin{array}{l}\text { K6a: nem } \\
\text { K6b: nem releváns } \\
\text { K6c: nem } \\
\text { K6d: nem }\end{array}$ \\
\hline K7 & Nem & \\
\hline
\end{tabular}

F7. táblázat

A kutatás hipotéziseinek és alhipotéziseinek összefoglaló értékelése

\begin{tabular}{l|c|l}
\hline Hipotézis & Hipotézis általános értékelése & \multicolumn{1}{|c}{ Alhipotézis részletes értékelése } \\
\hline H1 & Elfogadva & H1a: elfogadva; H1b: nem releváns; H1c: nem releváns; H1d: elfogadva \\
\hline H2 & Elutasítva & H2a: nem releváns; H2b: nem releváns; H2c: elutasítva; H2d: elutasítva \\
\hline H3 & Elutasítva & $\begin{array}{l}\text { H3a: elutasítva; H3b: elutasítva; } \\
\text { H3c: nem releváns; H3d: elutasítva }\end{array}$ \\
\hline H4 & Elutasítva & H4a: elutasítva; H4b: elutasítva; H4c: nem releváns; H4d: elutasítva \\
\hline H5 & Részben elfogadva & H5a: elutasítva; H5b: nem releváns; H5c: elutasítva; H5d: elutasítva \\
\hline H6 & Részben elfogadva & H6a: elfogadva; H6b: nem releváns; H6c: elfogadva; H6d: elutasítva \\
\hline H7 & Elutasítva & H7a: elutasítva; H7b: elutasítva; H7c: nem releváns; H7d: elutasítva \\
\hline H8 & Elutasítva & H8a: elutasítva; H8b: elutasítva; H8c: nem releváns; H8d: elutasítva \\
\hline H9 & Részben elfogadva & H9a: részben elfogadva; H9b: részben elfogadva \\
\hline
\end{tabular}

Statisztikai Szemle, 96. évfolụam 7. szóm 661-682. oldal 
F1. ábra. A Miles-Snow-féle stratégiai orientációkat mérö Segev-skála konfirmatív

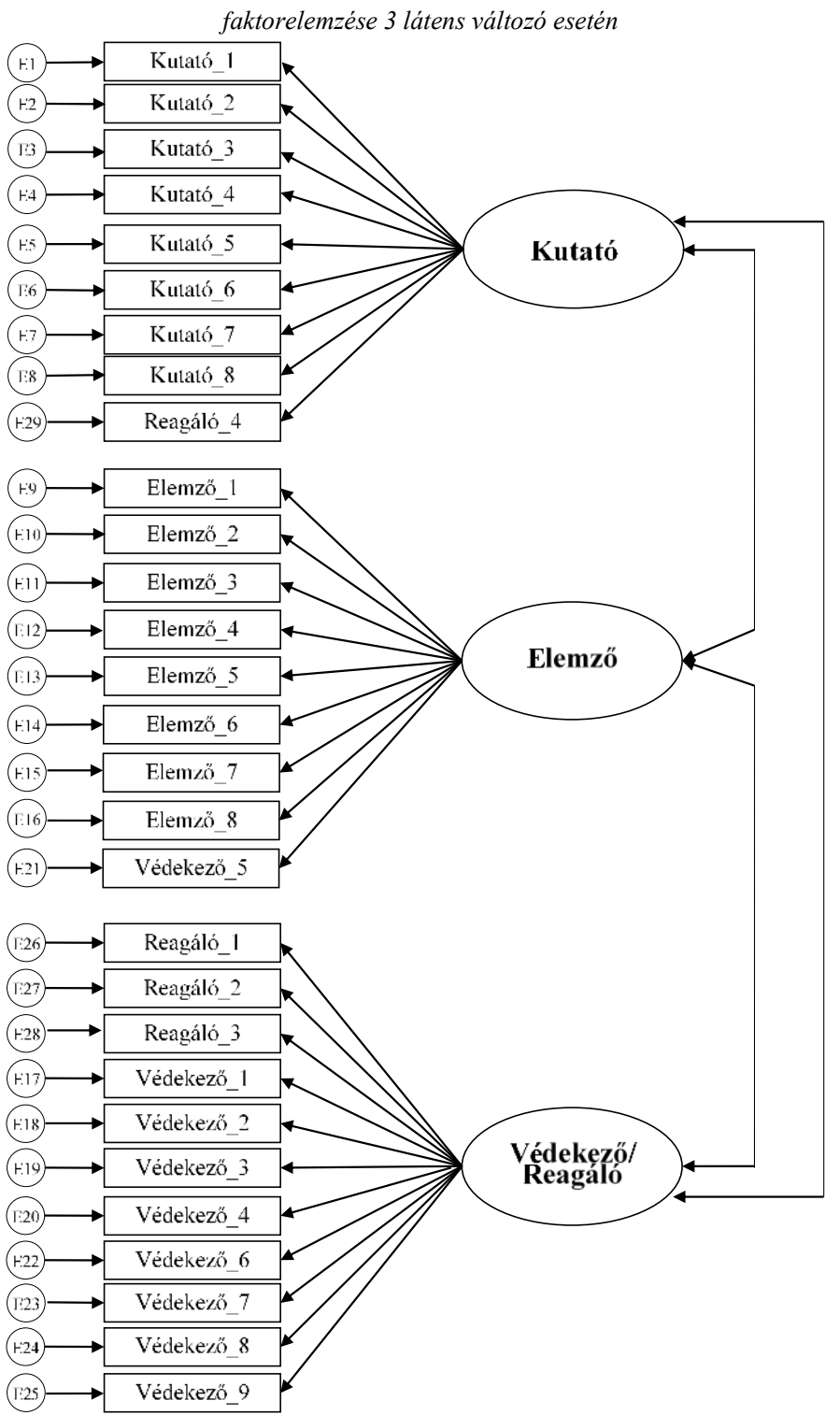

Megjegyzés. A stratégiai orientációkat mint látens konstrukciókat ovális alakzatban, a kérdőívben közvetlenül megkérdezett változókat téglalapokban, míg a manifeszt változókhoz kapcsolódó hibatagokat pedig kör alakzatban jelöltük. Az ábráról leolvasható, hogy a Védekező/Reagáló „mix” azonosításával - a Kutatókkal és Elemzőkkel együtt - 3 stratégiai orientációt figyeltünk meg a gyógyszertárak alkalmazkodásában. (Lásd az F1. táblázat K1-et.)

Forrás: Saját készítésü ábra Segev [1987] alapján. 


\section{Irodalom}

Bauer A. - Mitev A. Z. [2001]: Marketing a gyógyszertárban. Dictum Kiadó. Budapest.

BentLer, P. M. - BonetT, D. G. [1980]: Significance tests and goodness of fit in the analysis of covariance structures. Psychological Bulletin. Vol. 88. No. 3. pp. 588-606. http://dx.doi.org/10.1037/0033-2909.88.3.588

Bollen, K. A. [1989]: Structural equations with latent variables. John Wiley \& Sons. Hoboken. http://dx.doi.org/10.1002/9781118619179

BouRgEOIS, L. J. [1980]: Strategy and environment: a conceptual integration. Academy of Management Review. Vol. 5. No. 1. pp. 25-39. http://dx.doi.org/10.2307/257802

Chen, F. F. - Curran, P. J. - Bollen, K. A. - Kirby, J. - PaXton, P. [2009]: An empirical evaluation of the use of fixed cutoff points in RMSEA test statistic in structural equation models. Sociological Methods and Research. Vol. 36. No. 4. pp. 462-494. http://dx.doi.org/10.1177/0049124108314720

CHILD, J. [1972]: Organizational structure, environment and performance: the role of strategic choice. Sociology. Vol. 6. No. 1. pp. 1-22.

ChURChILL, G. Jr. [1979]: A paradigm for developing better measures for marketing constructs. Journal of Marketing Research. Vol. 16. No. 1. pp. 64-73. http://dx.doi.org/ $10.2307 / 3150876$

Coltman, T. - Devinney, T. M. - Midgley, D. F. - Venaik, S. [2008]: Formative versus reflective measurement models: two applications of formative measurement. Journal of Business Research. Vol. 61. Issue 12. pp. 1250-1262. http://dx.doi.org/10.1016/ j.jbusres.2008.01.013

Diamantopoulos, A. - Siguaw, J. A. [2006]: Formative versus reflective indicators in organisational measure development: a comparison and empirical illustration. British Journal of Management. Vol. 17. Issue 4. pp. 263-282. https://doi.org/10.1111/j.14678551.2006.00500.x

FARH, J. L. - HofFman, R. C. - Hegarty, W. H. [1984]: Assessing environmental scanning at the subunit level: a multitrait-multimethod analyis. Decision Sciences. Vol. 15. Issue 2. pp. 197219 http://dx.doi.org/10.1111/j.1540-5915.1984.tb01209.x.

FoRNELL, C. - LARCKER, D. F. [1981]: Evaluating structural equation models with unobservable variables and measurement error. Journal of Marketing Research. Vol. 18. No. 1. pp. 39-50. http://dx.doi.org/10.2307/3151312

GHOBADIAN, A. - JAMES, P. - LiU, J. - ViNEY, H. [1998]: Evaluating the applicability of the miles and snow typology in a regulated public utility environment. British Journal of Management. Vol. 9. Issue s1. pp. 71-83. https://doi.org/10.1111/1467-8551.9.s1.7

GHOBADIAN, A. - O'REAGAN, N. [2005]: Innovation in SMEs: the impact of strategic orientation and environmental perceptions. International Journal of Productivity and Performance Management. Vol. 54. Issue 2. pp. 81-97. https://doi.org/10.1108/17410400510576595

Groves, R. M. - Dillmann, D. A. - Eltinge, J. L. - Little, R. J. A. (eds.) [2001]: Survey Nonresponse. John Wiley \& Sons. Hoboken.

Henley, B. - Shook, C. L. - Peterson, M. [2006]: The presence of equivalent models in strategic management research using structural equation modeling: assessing and addressing the

Statisztikai Szemle, 96. évfolụam 7. szóm 661-682. oldal 
problem. Organizational Research Methods. Vol. 9. Issue 4. pp. 516-535. http://dx.doi.org/10.1177/1094428106290195

Hu, L. - Bentler, P. M. [1999]: Cutoff criteria for fit index the presence of equivalent models in strategic management research using structural equation modeling: assessing and addressing the problem es in covariance structure analysis: conventional criteria versus new alternatives. Structural Equation Modeling: A Multidisciplinary Journal. Vol. 6. Issue 1. pp. 1-55. https://doi.org/10.1080/10705519909540118

KaPlan, D. [2000]: Structural Equation Modeling: Foundations and Extensions. Sage Publications. Thousand Oaks.

Miles, R. E. - Snow, C. C. [1978]: Organisational Strategy, Structure and Process. McGraw Hill Book Company. New York.

Pillittere-Dugan, D. - Nau, D. P. - Mcdonough, K. - Pierre, Z. [2009]: Development and testing of performance measures for pharmacy services. Journal of the American Pharmacists Association. Vol. 49. Issue 2. pp. 212-219. http://dx.doi.org/10.1331/JAPhA.2009.09012

Podsakoff, P. M. - Mackenzie, S. B. - LeE, J. Y. - Podsakoff, N. P. [2003]: Common method biases in behavioral research: a critical review of the literature and recommended remedies. Journal of Applied Psychology. Vol. 88. No. 5. pp. 879-903. http://dx.doi.org/10.1037/00219010.88.5.879

SAJTOS L. - FACHE, M. [2005]: A strukturális egyenlőségek módszere és alkalmazása a marketingkutatásban. Marketing \& Menedzsment. XXXIX. évf. 4-5. sz. 99-111. old.

Savin, N. E. [1980]: The Bonferroni and Scheffe multiple comparison procedures. The Review of Economic Studies. Vol. 47. Issue 1. pp. 255-273. http://dx.doi.org/10.2307/2297112

SEGEV, E. [1987]: Strategy, strategy making, and performance in a business game. Management Science. Vol. 33. No. 2. pp. 258-269. http://dx.doi.org/10.1287/mnsc.33.2.258

Shook, C. L. - Ketchen, D. J. - Hult, G. T. M. - KaCMAR, K. M. [2004]: An assessment of the use of structural equation modeling in strategic management research. Strategic Management Journal. Vol. 25. Issue 4. pp. 397-404. http://dx.doi.org/10.1002/smj.385

SNOw, C. S. - HAMBRICK, D. C. [1980]: Measuring organisational strategies: some theoretical and methodological problems. Academy of Management Review. Vol. 5. No. 4. pp. 527-538. https://doi.org/10.5465/amr.1980.4288955

ZahrA, S. A. - PIERCE, J. A. II. [1990]: Research evidence on the Miles-Snow typology. Journal of Management. Vol. 16. No. 4. pp. 751-767. http://dx.doi.org/10.1177/014920639001600407 


\section{Summary}

The study examines the manifestation of Miles and Snow's strategic orientations and reveals their business performance implications in the domestic drug retail sector. In the first part, the strategic typology of Miles and Snow is introduced, and the specific mechanisms of the Hungarian public retail drug supply that is characterised by the blending microeconomic traits of public and private goods are highlighted. In addition, a conceptual model is set up, and research questions and hypotheses are formulated. The second part presents data collection and empirical methods, resuming research results and consequences. By applying multivariate statistical tools, the authors prove that the 4 , pure" ideal typical strategic orientations of Miles and Snow cannot be observed in the domestic drug retail sector. Moreover, they confirm that restrictive macroeconomic factors and unfavourable demand conditions can partially be compensated by the conscious choice and consistent implementation of proactive, market-oriented strategies. To this end, comprehensive development of business knowledge and managerial competencies of pharmacists is required. 